\title{
Contemporary Innovation Challenges - Future of Adoption Artificial Intelligence: Case of Estonia
}

EIS 14/2020

Contemporary Innovation Challenges Future of Adoption Artificial Intelligence: Case of Estonia

Submitted 05/2020

Accepted for publication $07 / 2020$

\section{Natalie Aleksandra Gurvits-Suits}

Tallinn University of Technology

\section{$\Gamma$ crossef http://dx.doi.org/10.5755/j01.eis.1.14.26143}

Nowadays artificial intelligence is gaining popularity and brings changes into everyday lives and business. Latest research outline various options and challenges related to the implementation of artificial intelligence in different fields (Garbuio\&Lin, 2019; Kumar et.al, 2019; Tambe et.al 2019). It is obvious that its adoption will have a notable significant impact on certain industries. However, it also requires complete understanding and awareness of main constraints and benefits. The aim of the present research is to find out the possibilities of adoption of the artificial intelligence in accounting industry in case of Estonia and its impact on the role of the accountant in the future.

The main research question focuses on whether Estonian accountants are aware of the new opportunities related to the implementation of artificial intelligence and their openness to these challenges. Authors conducted a survey among Estonian accounting professionals and the results revealed limited knowledge, with people being aware of the meaning but having little or no idea about the basic components of artificial intelligence and wide range of a potential application.

During the research, it became obvious that only few companies in Estonia are already using artificial intelligence: among the main reasons of non-adoption are lack of experience, lack of qualified professionals and the general complexity. Authors believe that the results of this study provide a starting point for companies involved in providing various modern technical support for accounting industry and may contribute to the raising awareness and further development of active successful adoption of artificial intelligence in Estonia.

KEYWORDS: artificial intelligence, accounting, financial accounting, reporting, skills.

Nowadays artificial intelligence is gaining popularity being widely adopted in the modern world (Chan 2020) and bringing major changes into everyday lives and business; supporting both social and economic activities and attracting attention in various countries on different continents (Lu et al. 2018). Its high growth potential has attracted close attention and according to Zawacki-Richter et al. (2019) has become "one of emerging fields in educational technology". And while it is much spoken and written about discussing pros and contras (Singh et al. 2020) still no single definition could be found in relevant literature. In authors opinion the one formulated by Tecuci (2011) stating that "artificial intelligence (AI) is the Science and Engineering domain concerned with the theory and practice of developing systems that exhibit the characteristics we associate with intelligence in human behaviour" could be considered as applicable to every industry and business area.

Such rapid growth and increasing attention have generated high research interest, identifying various options and challenges related to the implementation of artificial intelligence in differ-

Introduction and literature review

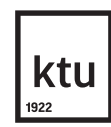

European Integration Studies No. 14 / 2020, pp. 217-225 doi.org/10.5755/j01.eis.1.14.26143 
ent fields (Garbuio\&Lin, 2019; Kumar et.al, 2019; Tambe et.al 2019). Findings of contemporary researchers reveal the results of application of artificial intelligence in telecommunication industry (Jiayin et.al 2007), digital media (Damiano et.al 2019), digital marketing (Zeeshan\&Saxena 2020) and engineering (Tzuc et.al 2020) outlining promising results and new possible areas of implementation withing each industry. Abeyratne (2017) has no doubt that with time artificial intelligence would play a vital role in air transport, and findings of Qian et al. (2020) suggest that its successful integration would result in achieving "smart process industry".

And if the implementation of artificial intelligence looks natural in the world of computer technologies (Tang et al. 2020) demanded and welcomed in medicine (Wilhelm, D.; Ostler, D.; Mueller-Stich, B.; et al. 2020; Herrmann et al. 2020), especially in trauma surgery (Tjardes, T.; Heller, R. A.; Pfoerringer, D.; et al. 2020), then it seems less real and therefore quite surprising that artificial intelligence methods are extensively used for forecasting of oil prices (Sehgal\&Pandey 2015), modernization of entrepreneurship (Safargaliev et al. 2020) and financial services (Arslanian\&Fischer 2019), there it comes to the question whether the implementation of artificial intelligence is safe enough or we are facing the threat: substitution of financial practitioners (Stein Smith 2020) or total machine takeover (Mainzer 2020). It is not a secret that to some extent everyone is concerned about the changes that would come along with the implementation of artificial intelligence as in spite of it strengths in knowledge representation, reasoning and planning (Qian et al. 2020) its encompassing is generating concerns about ethical perspectives and risks (Boddington 2017). Being intrinsically good the idea of the implementation of artificial intelligence could trigger emergence of various ethical issues (Neubert\&Montanez 2020) as in some cases the information technology is not uniting but separating people into "groups of truth" (Sikdar 2018). Moral aspect is also discussed by Danaher (2019), who is stating that the rise of artificial intelligence and robots will "suppress our moral agency and increase the expression of moral patiency" (Danaher 2019). Therefore, it is still unclear what personal traits will be required to enable successful cooperation of human and non-human intelligence and how we can prepare ourselves to the usage of artificial intelligence.

The scope of the present research is the usage of artificial intelligence in the accounting field, as the crucial point is that this area being quite computerized and digitalized nowadays, especially in Estonia, still requires significant human interaction. And while the usage of artificial intelligence could improve business efficiency and reduce number of errors, it may also cause the loose of job by accounting professionals (Shi 2020) by having a significant amount of jobs being taken by artificial intelligence (Brougham\&Haar 2017). Numerous researchers outline that artificial intelligence could be effectively used for external and internal audit and control (Askary et al. 2018; Bowling \& Meyer 2019; Munoko et al.2020) providing error-free and unbiased information, however, still there may appear tensions among stakeholders, which in turn may generate ethical conflicts (Munoko et al.2020).

However, it is obvious that one should agree with the opinion of leading auditing and accounting professional companies and organizations stating that it is a contemporary challenging technology (KPMG 2019) having high potential for change (KPMG 2020), making possible to "do things that have never been done before" (PWC 2017), which inspires new possibilities of operating business (EY 2020) and making ourselves ready for the new world of modern innovative technologies (ACCA).

The main aim of this research was to find out possibilities of adoption of the artificial intelligence in the field of accounting in case of Estonia and its impact on the role of the accountant in the future. The main research question focuses on whether Estonian accountants are aware of the challenges related to the implementation of artificial intelligence and their openness to these challenges. Authors are also willing to find out the main benefits and constraints associated to 
the implementation of artificial intelligence in accounting field in case of Estonia.

For the present study, the authors have chosen survey as a method of quantitative research due to a wide sample of respondents. The questionnaires were distributed via groups of professional accountants in Estonia during the period of 28.10.2019-24.11.2019 and 02.03.2020 - 10.04.2020. In total 152 responses were collected in the process. This information was compiled, analysed and results are summarized and presented in the clear and understandable way. The remainder of the paper is organized as follows: after the linkage of the research topic to current literature, authors provide a practical insight into the awareness of the artificial intelligence, main areas of implementation companies identifying the main reasons and associated benefits. Furthermore, authors present the results of the survey conducted among Estonian accounting professionals, and these findings are taken as a basis for concluding remarks.

The authors conducted a survey, which consisted of 12 questions related to the implementation of the artificial intelligence. One question was taken from the ACCA survey and the remaining were created by the authors. The languages of the questionnaire were Estonian and Russian. To present the questions and make it possible to collect data, an online survey engine Google Forms was used. The survey included one single choice question, where respondents were asked to choose one option from a list of arguments; one multiple choice questions, where respondents were asked to select several options and several linear scale question, where respondents were asked to select rank each argument from 1 (strong disagreement) to 5 (total agreement) in order to express their agreement or disagreement with each statement.

The survey was conducted among professional accountants in business and public organizations currently working in Estonia. Teachers and scholars from the accounting field were not included, except students currently undergoing an internship in the field of accounting. The questionnaires were distributed via groups of professional accountants in Estonia during the period of 28.10.2019-24.11.2019 with 87 responses received (this data was used by one of the authors in the master thesis) and 02.03.2020 - 10.04.2020 (65 responses were collected). In total 152 responses were collected in the process and authors consider this data as a basis for new and independent research presented in this article. This information was compiled and analysed. Table 1 shows demographic data of the survey.

\begin{tabular}{l|c}
\multicolumn{1}{c|}{ Status } & Sample \\
\hline Accountant & 90 \\
\hline Chief Accountant & 32 \\
\hline CFO & 5 \\
\hline Managing director & 4 \\
\hline Assistant accountant & 8 \\
\hline Accounting intern & 5 \\
\hline Other & 8 \\
\hline Total & 152 \\
\hline Education & \\
\hline Bachelor & 32 \\
\hline Master & 37 \\
\hline
\end{tabular}

\begin{tabular}{l|c|c}
\multicolumn{1}{|c|}{ Status } & Sample \\
\hline Other & & 43 \\
\hline Total & & 152 \\
\hline & Work experience \\
\hline$<4$ & 44 \\
\hline $5-9$ & 28 \\
\hline $10-14$ & 33 \\
\hline $15-19$ & 24 \\
\hline $20-24$ & 16 \\
\hline$>25$ & 7 \\
\hline Total & 152 \\
\hline
\end{tabular}

Source: author's construction based on the results of the conducted survey

\begin{tabular}{l|c}
\multicolumn{1}{|c}{$\begin{array}{c}\text { Status } \\
\text { Type of the company }\end{array}$} & Sample \\
\hline Public & 10 \\
\hline Private & 142 \\
\hline Total & 152 \\
\hline \multicolumn{1}{|c}{ Size of company } \\
\hline 1-9 employees & 55 \\
\hline 10-49 employees & 59 \\
\hline 50-249 employees & 18 \\
\hline More than 250 & 19 \\
employees & 1 \\
\hline Other & 152 \\
\hline Total &
\end{tabular}

Table 1

Demographic data of the survey 


\section{Results}

\section{Table 2}

Main reasons, associated benefits and areas related to implementation of artificial intelligence in the field of financial accounting (in \% of respondents)
Data of the table 1 makes it evident that most respondents are either accountants or chief accountants with either bachelor or master's degree mostly employed by private companies. The next section represents the results of the survey.

The aim of the first question was to find out whether respondents are familiar with the focus of the survey and the results revealed that the majority of respondents (82\%) are familiar with the term "artificial intelligence", however, the awareness of related terms is quite low: Big Data 54\%, Machine Learning - 34\%, Deep Learning - 27\%, Artificial Neural Network - 20\%, Expert Systems $-17 \%$ and for the $18 \%$ of the respondents all terms are non-familiar. In author's opinion, this is due to the increasing appearance of the term "artificial intelligence in mass media and various journals. And while other terms seem to be more specific and less frequently cited, people seem to have no related associations.

Based on the ACCA survey authors also investigated whether the artificial intelligence is also implemented in the companies represented by the respondents (ACCA...2019), the results of the survey revealed that: it is actively used only in $11 \%$ of companies, $51 \%$ have no plans for implementation, $24 \%$ are not able to answer this question, $10 \%$ of the companies are at the stage of discussing possible ways of implementation, $2 \%$ are at the test stage and $2 \%$ are starting to implement.

It should also be noted that results of the survey revealed that $69 \%$ of respondents strongly disagree or rather agree with the statement that artificial intelligence can totally substitute accountant, while $23 \%$ were not able to answer and $9 \%$ agreed with this statement.

Table 2 summarizes main reasons why companies should use artificial intelligence as well as the main areas of implementation.

\begin{tabular}{c|c|c|c}
\hline $\begin{array}{c}\text { Main reasons and associated } \\
\text { benefits }\end{array}$ & $\begin{array}{c}\text { Strongly agree or } \\
\text { rather agree }\end{array}$ & Main areas & $\begin{array}{c}\text { Strongly agree or rather } \\
\text { agree }\end{array}$ \\
\hline $\begin{array}{c}\text { Saving time } \\
\text { Automation of routine job } \\
\text { processes, constant access to } \\
\text { data }\end{array}$ & $97 \%$ & Financial accounting & $97 \%$ \\
\hline $\begin{array}{c}\text { Increased speed of data } \\
\text { processing, data and memory size }\end{array}$ & $97 \%$ & Cost accounting & $97 \%$ \\
\hline Data reliance & $93 \%$ & Financial planning & $88 \%$ \\
\hline Increased productivity & $91 \%$ & Forensic accounting & $87 \%$ \\
\hline $\begin{array}{c}\text { Reduction of paper usage } \\
\text { Reduction of errors }\end{array}$ & $90 \%$ & Accounting for & $86 \%$ \\
\hline $\begin{array}{c}\text { Saving money (reduction of } \\
\text { expenses) }\end{array}$ & $86 \%$ & salaries and wages & $78 \%$ \\
\hline Increased trustworthiness and & $78 \%$ & Taxation & $77 \%$ \\
\hline accuracy & $70 \%$ & Internal audit & $75 \%$ \\
\hline
\end{tabular}

Source: author's construction based on the results of the conducted survey

Data presented in the table 2 makes it obvious that the implementation of artificial intelligence should be applicable mostly to financial accounting and reporting as it saves time, deals with various routine tasks, and reduces usage of paper. However, the areas of accounting requiring also managerial and audit skills seems to be less suitable for the interaction of non-human intelligence. More detailed information about the tasks that might be performed by artificial intelligence is presented in table 3 . 


\begin{tabular}{c|c}
\hline Automated tasks & Strongly agree or rather agree \\
\hline Issuance and acceptance of invoices & $95 \%$ \\
\hline Financial reporting & $95 \%$ \\
\hline Yield forecasting & $93 \%$ \\
\hline Filling in and submitting declaration forms & $93 \%$ \\
\hline Real time inventory accounting & $92 \%$ \\
\hline Analysis of debts and receivables & $89 \%$ \\
\hline Forecasting and optimisation of costs and expenses & $86 \%$ \\
\hline Real-time assets accounting & $85 \%$ \\
\hline Forecasting and optimisation of investments & $82 \%$ \\
\hline Budgeting & $81 \%$ \\
\hline Forecast and optimization of taxes & $70 \%$ \\
\hline Strategical planning & $63 \%$ \\
\hline Managerial reporting & $49 \%$ \\
\hline Non-financial reporting & $46 \%$ \\
\hline
\end{tabular}

Table 3

Main tasks, which could be automated by the implementation of artificial intelligence in the field of accounting (in \% of respondents)

Source: author's construction based on the results of the conducted survey

As becomes evident from the table 3 artificial intelligence could automate mostly standard process, there operations do not vary widely: issuance invoices, preparing financial reports and taxation declarations, while more complicated tasks involving non-standard situations and approaches like optimization of taxes, non-financial reporting and managerial reporting still require human efforts, knowledge and skills. These findings also supported by the results presented in the table 4, confirming that artificial intelligence is mostly suitable for data processing, controlling and monitoring and least suitable for handling problems requiring creative and critical thinking, ethical consideration and the ones handling force-majeure situations.

\begin{tabular}{l|c|l|c}
\hline $\begin{array}{l}\text { Main constraints in accounting field } \\
\text { in Estonia }\end{array}$ & $\begin{array}{c}\text { Strongly agree } \\
\text { or rather agree }\end{array}$ & $\begin{array}{c}\text { Main tasks non-suitable for } \\
\text { implementation }\end{array}$ & $\begin{array}{c}\text { Strongly agree } \\
\text { or rather agree }\end{array}$ \\
$\begin{array}{l}\text { Shortage of implementation } \\
\text { experience }\end{array}$ & $99 \%$ & $\begin{array}{l}\text { Solving of problems requiring } \\
\text { creative thinking }\end{array}$ & $93 \%$ \\
\hline $\begin{array}{l}\text { Shortage of professionals } \\
\text { Complexity of artificial intelligence }\end{array}$ & $96 \%$ & Consulting & $92 \%$ \\
\hline Need of large investments & $78 \%$ & $\begin{array}{l}\text { Finding solutions to ethical } \\
\text { problems and dilemmas }\end{array}$ & $91 \%$ \\
\hline $\begin{array}{l}\text { Complexity of calculating the cost of } \\
\text { implementation of artificial intelligence }\end{array}$ & $66 \%$ & Management of exceptions & $90 \%$ \\
\hline Shortage of rules and standards & $66 \%$ & Discussions & $86 \%$ \\
\hline Big associated risks & $61 \%$ & $\begin{array}{l}\text { Handling of force-majeure } \\
\text { situations }\end{array}$ & $84 \%$ \\
\hline Ethical consideration & $53 \%$ & Interpretation of data and results & $76 \%$ \\
\hline Distrust & $43 \%$ & Controlling and monitoring & $53 \%$ \\
\hline
\end{tabular}

Table 4

Main constraints and tasks making implementation of artificial intelligence not possible in Estonia (in \% of respondents)

Source: author's construction based on the results of the conducted survey 
Table 5

Main skills required for successful cooperation and implementation of artificial intelligence (in \% of respondents)
Among the main obstacles of non-implementation of artificial intelligence is Estonia respondents outlined lack of experience, experienced professionals, and the complexity of this process in general. They also disclosed the main skills and personal traits required for successful implementation, which are summarized and presented in table 5.

As clearly illustrated by table 5 in order to cope with the usage of artificial intelligent at workplace accountant needs to be strong in IT and digital fields, be creative and able to think critically as well as willing to keep up to date with the latest developments in the area of accounting; while social and managerial skills are least required as no active communication process is taking place. However, these changes and innovations would require accountants to become more adaptable, cooperative, ethical, and open-minded.

\begin{tabular}{l|c|c|c}
\hline \multicolumn{1}{c|}{ Main personal and interpersonal skills } & $\begin{array}{c}\text { Strongly agree or } \\
\text { rather agree }\end{array}$ & $\begin{array}{c}\text { Main personality traits } \\
\text { IT knowledge and skills }\end{array}$ & $\begin{array}{c}\text { Strongly agree or } \\
\text { rather agree }\end{array}$ \\
\hline Digital competence & $98 \%$ & Adaptable & $97 \%$ \\
\hline Continuing professional development skills & $95 \%$ & Ethical & $93 \%$ \\
\hline $\begin{array}{l}\text { Data processing, processes monitoring } \\
\text { and evaluation skills }\end{array}$ & $93 \%$ & Open minded & $86 \%$ \\
\hline Critical and creative thinking skills & $92 \%$ & Creative & $84 \%$ \\
\hline $\begin{array}{l}\text { Knowledge of accounting standards and } \\
\text { legislations }\end{array}$ & $92 \%$ & Critical ability & $83 \%$ \\
\hline Managerial skills & $54 \%$ & Openness & $79 \%$ \\
\hline Social skills & $53 \%$ & Helpful & $68 \%$ \\
\hline
\end{tabular}

Source: author's construction based on the results of the conducted survey

The results of the research revealed that in general respondents are aware of the artificial intelligence, however they consider it to be quite complex, time and resource consuming and its implementation looks complicated. This is proved by the fact that only few companies are either actively implementing it in their everyday business activities and several are considering the implementation. In line with findings of several researchers it seems that the usage of artificial intelligence in accounting field could be most successfully used in financial accounting and reporting as well as filling in various taxation declarations, i.e. quite standardized areas with strict guidelines and requirements. While when it comes to more creative and open-minded fields like managerial accounting, strategical planning, and non-financial reporting the human factor plays a primary role. In authors opinion, still most respondents associate artificial intelligence with automated machine, which could be used to optimize certain routine processes, but has little to do with tasks requiring creative and critical thinking. And while respondents agreed that the implementation of artificial intelligence may improve job productivity, assist in data processing and monitoring and save time it is still quite expensive and non-useful for consulting, managing of situations requiring creative and non-standard thinking or the ones involving ethical issues. It was also interesting that while audit companies being excited and welcoming the new world of challenges and changes enabled by the artificial intelligence, according to the survey results the internal audit were not number one in the list of possible areas of its implementation. 
It should also be noted that the results of the study indicate that as artificial intelligence is regarded by respondents as automated machine, therefore, to cooperate successfully, it would require adaptive and cooperative human counterpart with high level of IT knowledge and nonstop learning ability, i.e. "automated human" with social and managerial skills pushed to the side. These findings provide evidence on the possible benefits and obstacles of the implementation of artificial intelligence in the accounting area. However, these results should be treated with caution as the sample of the respondents is quite small and while the rate of response was quite high, still the results of the survey cannot be generalized. It is also important that most respondents are employed by micro or small private companies, with only one or two accountants performing all the job and the responses bias may have occurred from their side as they might me be concerned that the artificial intelligence could substitute their functions.

Nevertheless, this study provides an overview of the future possibilities of adoption artificial intelligence in accounting in the case of Estonia confirming that it could be used in numerous fields of accounting, successfully performing various tasks requiring successful cooperation with an educated, ethical and open-minded accounting specialist willing to keep-up to date with the area of expertise.

Abeyratne R. (2017) Artificial Intelligence and Air Transport. In: Megatrends and Air Transport. Springer, Cham. doi.org/10.1007/978-3-319-61124-2_5. https://doi.org/10.1007/978-3-319-61124-2

ACCA (2019). The impact of Digital and Artificial Intelligence on audit and finance professionals: harnessing the opportunities of disruptive technologies Retrieved April 12020 from https://www.accaglobal. com/gb/en/technical-activities/technical-resources-search/2018/december/impact-of-digital-andai-on-audit-.html

Arslanian H., Fischer F. (2019) Applications of Artificial Intelligence in Financial Services. In: The Future of Finance. Palgrave Macmillan, Cham. doi. org/10.1007/978-3-030-14533-0_15. https://doi. org/10.1007/978-3-030-14533-0_15

Askary S., Abu-Ghazaleh N., Tahat Y.A. (2018) Artificial Intelligence and Reliability of Accounting Information. In: Al-Sharhan S. et al. (eds) Challenges and Opportunities in the Digital Era. I3E 2018. Lecture Notes in Computer Science, vol 11195. Springer, Cham. doi. org/10.1007/978-3-030-02131-3_28. https://doi. org/10.1007/978-3-030-02131-3_28

Boddington P. (2017) Introduction: Artificial Intelligence and Ethics. In: Towards a Code of Ethics for Artificial Intelligence. Artificial Intelligence: Foundations, Theory, and Algorithms. Springer, Cham. https://doi. org/10.1007/978-3-319-60648-4_1

Bowling, S., \& Meyer, C. (2019). How we successfully implemented $\mathrm{Al}$ in audit. Journal of Accountancy,227(5), 26-28. https://doi.org/10.1108/MEDAR-12-2018-0409
Brougham D.; Haar J. (2017). Smart Technology, Artificial Intelligence, Robotics, and Algorithms (STARA): Employees' perceptions of our future workplace. 24: 239-257. DOI: https://doi.org/10.1017/jmo.2016.55

Chan, B. (2020). The rise of artificial intelligence and the crisis of moral passivity. Al \& Soc. https://doi. org/10.1007/s00146-020-00953-9

Danaher, J. (2019). The rise of the robots and the crisis of moral patiency. Al \& Soc 34, 129-136. https://doi. org/10.1007/s00146-017-0773-9

Damiano R., Lombardo V., Monticone G., Pizzo A. (2019) Artificial Intelligence for Dramatic Performance. In: Alviano M., Greco G., Scarcello F. (eds) Al*IA 2019 - Advances in Artificial Intelligence. Al*IA 2019. Lecture Notes in Computer Science, vol 11946. Springer, Cham. https://doi.org/10.1007/978-3-03035166-3_38

EY. (2020). Al - our latest thinking. Retrieved April 1 2020 from https://www.ey.com/en_au/ai

Garbuio M., Lin N. (2018). Artificial Intelligence as a Growth Engine for Health Care Startups: Emerging Business Models. California Management Review 61: 59-83. https://doi.org/10.1177/0008125618811931

Herrmann, D.; Oggiano, M.; Hecker, E.(2020). Application of artificial intelligence in thoracic surgery. CHIRURG. 91: 206-210. Special Issue. DOI: 10.1007/ s00104-019-01089-3. https://doi.org/10.1007/ s00104-019-01089-3

Jiayin Qi, Feng Wu, Ling Li, Huaying Shu (2007). Artificial intelligence applications in the telecommunications industry. Expert Systems 24(4):271- 
291. DOI: 10.1111/j.1468-0394.2007.004 https://doi. org/10.1111/j.1468-0394.2007.00433.x

KPMG (2019). Al transforming the enterprise. Retrieved April 1, 2020 from https://advisory.kpmg.us/ articles/2019/ai-transforming-enterprise.html

KPMG (2020). Al: The new power generation. Retrieved April 1, 2020 from https://home.kpmg/xx/en/ home/insights/2020/02/ai-the-new-power-generation.html.

Kumar, V., Rajan, B., Venkatesan, R., \& Lecinski, J. (2019). Understanding the Role of Artificial Intelligence in Personalized Engagement Marketing. California Management Review, 61(4), 135-155. https:// doi.org/10.1177/0008125619859317

Lu, H., Li, Y., Chen, M. et al. (2018). Brain Intelligence: Go beyond Artificial Intelligence. Mobile Netw Appl 23, 368-375. https://doi.org/10.1007/s11036-017-0932-8

Mainzer K. (2020) How Safe Is Artificial Intelligence? In: Artificial intelligence - When do machines take over? Technik im Fokus. Springer, Berlin, Heidelberg. https://doi.org/10.1007/978-3-662-59717-0

Munoko, I., Brown-Liburd, H.L. \& Vasarhelyi, M. (2020). The Ethical Implications of Using Artificial Intelligence in Auditing. J Bus Ethics. https://doi.org/10.1007/ s10551-019-04407-1

Neubert, M.J.; Montanez, G.D. (2020). Virtue as a framework for the design and use of artificial intelligence. BUSINESS HORIZONS. 63:195-204. oi.org/10.1016/j.bushor.2019.11.001 https://doi. org/10.1016/j.bushor.2019.11.001

PWC. (2017). Global Artificial Imtelligence Study. Retrieved April 1, 2020 from https://www.pwc.com/ gx/en/issues/data-and-analytics/publications/artificial-intelligence-study.html

Qian, F.; Gao, H.; Huang, B.; Bogle, D. (2020). Guest Editorial: Special Section on Smart Process Manufacturing Driven by Artificial Intelligence. IEEE TRANSACTIONS ON INDUSTRIAL INFORMATICS. 4: 27652766. DOI: 10.1109/TII.2019.2960014 https://doi. org/10.1109/TII.2019.2960014

Safargaliev M.F., Kitsay Y.A., Egorova E.N., Ermolina L.V. (2020) Modernization of Modern Entrepreneurship on the Basis of Artificial Intelligence. In: Popkova E., Sergi B. (eds) The 21st Century from the Positions of Modern Science: Intellectual, Digital and Innovative Aspects. ISC 2019. Lecture Notes in Networks and Systems, vol 91. Springer, Cham. doi.org/10.1007/978-3-030-32015-7_39 https://doi. org/10.1007/978-3-030-32015-7_39
Sehgal, N., Pandey, K.K. (2015). Artificial intelligence methods for oil price forecasting: a review and evaluation. Energy Syst 6, 479-506. https://doi.org/10.1007/ s12667-015-0151-y

Shi Y. (2020) The Impact of Artificial Intelligence on the Accounting Industry. In: Xu Z., Choo KK., Dehghantanha A., Parizi R., Hammoudeh M. (eds) Cyber Security Intelligence and Analytics. CSIA 2019. Advances in Intelligent Systems and Computing, vol 928. Springer, Cham. doi.org/10.1007/978-3-030-15235-2_129 https://doi.org/10.1007/978-3-030-15235-2_129

Sikdar, S. (2018). Artificial intelligence, its impact on innovation, and the Google effect. Clean Techn Environ Policy 20, 1-2. https://doi.org/10.1007/s10098017-1478-y

Singh G., Garg V., Tiwari P. (2020) Application of Artificial Intelligence on Behavioral Finance. In: Castillo O., Jana D., Giri D., Ahmed A. (eds) Recent Advances in Intelligent Information Systems and Applied Mathematics. ICITAM 2019. Studies in Computational Intelligence, vol 863. Springer, Cham. doi. org/10.1007/978-3-030-34152-7_26 https://doi. org/10.1007/978-3-030-34152-7_26

Stein Smith S. (2020) Artificial Intelligence. In: Blockchain, Artificial Intelligence and Financial Services. Future of Business and Finance. Springer, Cham doi.org/10.1007/978-3-030-29761-9_6 https://doi. org/10.1007/978-3-030-29761-9_6

Tambe, P., Cappelli, P., \& Yakubovich, V. (2019). Artificial Intelligence in Human Resources Management: Challenges and a Path Forward. California Management Review, 61(4), 15-42. https://doi. org/10.1177/0008125619867910

Tang J., Yuan S., Zhou Y. (2020) Retrospect and Prospect of Artificial Intelligence Research in China. In: Chinese Academy of Sciences et al. (eds) China's e-Science Blue Book 2018. Springer, Singapore https://doi. org/10.1007/978-981-13-9390-7_6

Tecuci G. (2011). Artificial intelligence. WIREs Comput Stat 2012, 4:168-180. doi: 10.1002/wics.200 https:// doi.org/10.1002/wics.200

Tjardes, T; Heller, R.A.; Pfoerringer, D.; Lohmann, R. Back, DA (Back, David A. (2020). Artificial intelligence in orthopedics and trauma surgery. 91: 201-205 Special Issue: SI. DOI: 10.1007/s00104-019-01091-9 https://doi.org/10.1007/s00104-019-01091-9

Tzuc, O.M.; Livas-Garcia, A; Torres, MJ; Cruz May, E.Lopez-Manrique, LM ; Bassam, A. (2020). Artificial Intelligence Techniques for Modeling Indoor Building 
Temperature under Tropical Climate Using Outdoor Environmental Monitoring. JOURNAL OF ENERGY ENGINEERING. 146.04020004. DOI: 10.1061/(ASCE) EY.1943-7897.0000649 https://doi.org/10.1061/ (ASCE)EY.1943-7897.0000649

Wilhelm, D; Ostler, D; Mueller-Stich, B.; Lamade, W.; Stier, A; Feussner, H. (2020). Artificial intelligence in general and visceral surgery. 91: 181-189 Special Issue: SI. DOI: 10.1007/s00104-019-01090-w https:// doi.org/10.1007/s00104-019-01090-w
Zawacki-Richter, O., Marín, V.I., Bond, M. et al. (2019). Systematic review of research on artificial intelligence applications in higher education - where are the educators? Int J Educ Technol High Educ 16, 39. https:// doi.org/10.1186/s41239-019-0171-0

Zeeshan, Mohd \& Saxena, Komal. (2020). Explorative Study of Artificial Intelligence in Digital Marketing. DOI: 10.1007/978-3-030-43192-1_107 https://doi. org/10.1007/978-3-030-43192-1_107

\section{GAVRILOVA VALERIA}

MA

Metaan AS

\section{Fields of interests}

Financial accounting and Reporting.

\section{Address}

Laki põik 6, 12915, Tallinn, Estonia.

E-mail: valeriagavrilova8@gmail.com

\section{GURVITSH-SUITS NATALIE ALEKSANDRA}

PhD

Tallinn University of Technology

\section{Fields of interests}

CSR, Social Audit, Financial and Non-Financial Reporting.

\section{Address}

Ehitajate tee 5, 19086, Tallinn, Estonia.

E-mail: natalja.gurvits@taltech.ee
About the authors 